\title{
The New World Power
}

American Foreign Policy, 1898-1917

\author{
ROBERT E. HANNIGAN
}

\section{$\overline{\text { PENN }}$}

University of Pennsylvania Press

Philadelphia 
Copyright @ 2002 University of Pennsylvania Press All rights reserved

Printed in the United States of America on acid-free paper

$$
\begin{array}{llllllllll}
10 & 9 & 8 & 7 & 6 & 5 & 4 & 3 & 2 & 1
\end{array}
$$

Published by

University of Pennsylvania Press

Philadelphia, Pennsylvania 191044011

Library of Congress Cataloging-in-Publication Data

The new world power : American foreign policy, 1898-1917/

Robert E. Hannigan.

p. c.m.

ISBN 0-8122-3666-1 (acid-free paper)

Includes bibliographical references and index.

1. United States-Foreign relations-1865-1921. I. Title

E744.H353 2002

327.7321

2002020424 
This page intentionally left blank 
This page intentionally left blank 
For Irene and Ted 
This page intentionally left blank 